\title{
A Utah Success Story: \\ Making Recreation \& Agriculture Compatible
}

\section{This Utah farm family has been able to maintain their agricultural roots even as North America's fifth largest ski resort developed nearby.}

\author{
By Kindra Gordon
}

I t's been an all too common occurrence: Usually when development for housing or recreation moves into an area, it is at the expense of agriculture-which is forced to move out.

But near Park City, Utah, Steve Osguthorpe and his family have worked with developers to maintain their sheep operation and make it compatible with the nearby ski resort - The Canyons - which has grown to be North America's fifth largest ski area.

As one would expect, snow skiing is the primary activity on the mountainous land during the winter months, but in the summer and fall, nearly 3,000 sheep graze the grassy ski runs and resort lands even while tourists enjoy the scenic beauty of the area.

"Recreation and agriculture can be compatible," says Osguthorpe of the unique arrangement. He reports that it's been a win-win situation for his family farm and for the resort.

"The developers of the resort wanted to keep the area natural, and visitors really seem to enjoy seeing the sheep out grazing," he says. Keeping agricultural use on the land has also helped the resort keep their taxes lower.

For the Osguthorpe family, the arrangement has meant they can stay in the area that Steve's father Dr. D.A. Osguthorpe first established the ranch on in the late 1940s. As another benefit, Osguthorpe says, "It's an opportunity to show the public that we ranchers are stewards of the land and want to take care of it better than anyone else."

\section{A Long History of Stewardship}

Of the region that now attracts over 500,000 visitors each year, Osguthorpe admits many people might have sold their ranch and moved to a less touristy area, but he says his family has made the decision to stay. He tells that his father, who graduated as a veterinarian from Colorado State University in 1943, had foresight early on that Park City would likely be a resort town someday.

"From his experience in Colorado, he saw places like Estes Park and recognized the potential in Utah. When he came to Park City, he was the vet for horses used in the mines, and eventually he was able to buy seven ranches around Park City from 1945 to 1951 ," Osguthorpe says.

He adds, "My dad always knew the potential of the area for recreation development."

But in the early years, agriculture was the primary land use and the Osguthorpe family operated a dairy. Steve added sheep to the farm when he was in junior high. He then attended Utah State University and earned a degree in Animal Science before returning to the family farm and marrying his wife Vickie, a local Park City girl in the 1970s. This generation of Osguthorpe's continued to operate the dairy as they raised six sons and one daughter.

However, by the late 1980s, Park City began to develop around them. When the road needed to be widened, the Osguthorpe's 200 head dairy was taken through a process called condemnation. Then, through the same process, 40 acres of their land was taken for a middle school. "We haven't sold any ground, it's been taken through condemnation," says Osguthorpe. 
Eventually, the Osguthorpes relocated their farm headquarters to the town of Delta 140 miles southwest of Salt Lake City. Today, this ranch serves as their winter location, where they also operate a feedlot for cattle and their Columbia-Rambouilet crossbred sheep. But in the summer months, livestock still graze up near Park City on Forest Service permits and on the Osguthorpe land the ski resort now has access to through an easement.

Our family made the decision if we were going to farm and ranch here, we had to get involved in recreation, or else sell out and leave," Osguthorpe adds.

\section{Making It Work}

Despite the changing of the times from agricultural to development uses, the Osguthorpes have found ways to make the multiple land uses work.

First established as small ski area, the resort that neighbored their land was bought out by the American Skiing Company and renamed The Canyons about eight years ago. It was at that time the development moved into high gear.

But to do so, the new resort needed more land, which the Osguthorpe family granted them access to through an easement. However, in making the arrangements, Osguthorpe who serves as vice president of Utah Farm Bureau and on the board of the Utah Grazingland Network, was able to be hired as a consultant in overseeing management of the land - and keeping the option to graze it.

"I was worried about the mountain streams, the wildlife and the grazing. When snow melts in spring, that's where we get our water. So I put that as top priority to protect the land and the vegetation even though the area was being developed," he says.

For instance, as new ski runs were cut and lifts put in, he worked to develop a grass seed mix to quickly revegetate the slopes. As a result, Osguthorpe reports that they now have more forage available than before the development, and he has actually been able to increase the number of sheep grazing the area.

Gary Gerth, Field Director of the Utah Grazingland Network, (which is the state's 501 (c)(3) non-profit organization with a 15 member Board of Trustees, most of whom are ranchers or ranch managers,) reports that Osguthorpe's reclamation efforts of these disturbed sites has been outstanding. "They operate at an elevation where Canada thistle usually flourishes due to a soil disturbance, but very little thistle is to be seen," he says.

Osguthorpe's reseeding process includes broadcasting a grass-alfalfa mix over an area promptly after it has been disturbed. Then a 2 inch deep mulch of straw is hand spread over the site, and sheep are trailed over the reseeded areas to work the

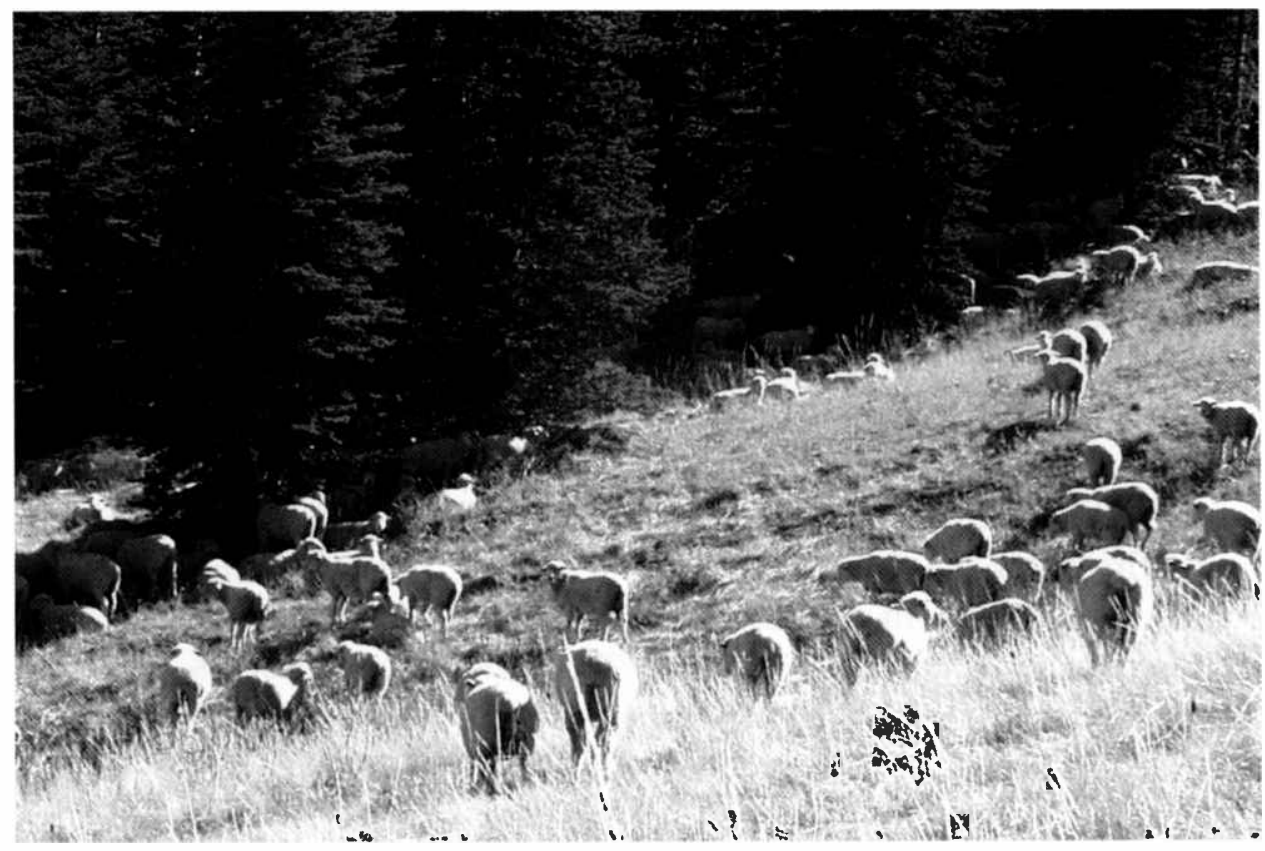


seed into the soil. The following spring these areas are not grazed, and in time the introduced species give way to native species.

From his experiences, Osguthorpe says, "I'm really in favor of management of land. Where we graze or log, we can see the benefits to the land. There is just more wildlife and more forage production," Osguthorpe adds.

A typical year now includes lambing the sheep near the ranch headquarters at Delta in early May, and then moving the herd of about 3,000 head to the ski resort by June 1. Some of the sheep may be moved to Forest permit allotments around July 1, and then the entire group is returned to the ski area to graze off the ski runs in September and October. Roundups are conducted in the resort parking lot.
Guard dogs are also an important part of the operation and are used to control mountain lions and coyotes. "Without our guard dogs we wouldn't be in business today," Osguthorpe says.

While this family farm operation has endured amidst the winter ski runs and summer horseback and mountain bike trails, Osguthorpe says he hopes the biggest lesson to other producers and landowners is that multiple uses such as these can co-exist with livestock grazing.

This article provided as a courtesy by the Grazing Lands Conservation Initiative, for more on GLCI visit www.glci.org.

\section{An Educational Opportunity}

While most producers might view sharing their land with the public as a burden, Utah's Steve Osguthorpe has turned it into an opportunity.

"By staying here, we've had the opportunity to educate the public," he says of the arrangement to keep his sheep on land now used by a popular ski resort.

Osguthorpe has even had the chance to share his story with some well-known people. For instance, during the 2002 Winter Olympics in Salt Lake City, the Today Show and evening news with Tom Brokaw were broadcast from The Canyons, the resort the Osguthorpes are working with. "We got to know Katie Couric and Al Roker and some of the others quite well. We took them snowmobiling and out on horseback, and they were all impressed that the area was developed, but yet has been kept so natural," Osguthorpe says.

Last summer Secretary of the Interior Gale Norton also visited the Osguthorpe's and toured a forest rehabilition project that is underway. Again, Osguthorpe says this was opportunity to share firsthand with a political decisionmaker the important benefits of production agriculture on the land.

Because of their ability to adapt to the tourism industry around them, the Osguthorpes have also been able to keep all of their children involved in the farm operation. The four oldest sons, who have finished college, help with the farm and operate snowmobile tours in the winter and guided horse tours in the summer.

Similarly in South Dakota, rancher Gene Williams has partnered with the public to help educate them about conservation and ranch management.

Williams' family ranch is located adjacent to South Dakota's Badlands National Park near Wall, and he has worked tirelessly to inform and educate tourists and park staff about the benefits provided by ranching and conservation practices. Currently, the Badlands has a herd of buffalo that graze in a wilderness area, but cattle grazing is not allowed in the Park.

"Our goal is to show that cows aren't something that's evil, but something to be managed," Williams says.

To that end, he has made a ranch-access arrangement with the park to help provide educational opportunities for park visitors to learn about the workings of his adjacent cattle ranch. The agreement includes plans for a six-milelong bicycle trail that features signposts with full-color-photos and text describing the land and its inhabitants, as well as walk-in hunting areas.

"The hope was that people who aren't familiar with the positives that result from active management tied to agriculture will understand and see some of the benefits provided to wildlife, water quality and landscape scenery from cattle ranching," Williams says. "We want the public to be aware of the benefits of conservation by landowners, so they support the use of tax dollars for conservation." 


\section{Resource Roundup}

A new ranch management program will make its debut this fall at Texas A\&M UniversityKingsville. The King Ranch Institute for Ranch Management is a master's degree program designed to train students in all areas of ranch management from range and wildlife sectors to finance.

Barry Dunn, formerly a range livestock production specialist at South Dakota State University, Brookings, is the program's endowed chair and executive director.

The program will be a two-year intensive study and will include two internships in which students will complete case studies on the most well-managed ranches in the U.S., and possibly international ranches.

The Institute's admission standards include a bachelor's degree in animal science, range and wildlife management or business with a minimum 3.0 GPA. Previous work experience on a ranch or farm is also preferred. Two students will be accepted into the school this fall. In fall 2005, four additional students will be added.

Dunn says they are actively pursuing non-traditional students who have served in the workforce in some capacity and want to return to school to earn a master's degree.

Several new and improved grass varieties were released this spring. Three wheatgrass varieties developed by scientists at USDA-ARS and the University of Nebraska-Lincoln and adapted to the central and northern Great Plains include:

NU-ARS AC2, a Fairway type of crested wheatgrass. Adapted to semiarid regions, it yields equal to some of the best standard crested wheatgrass varieties even though it's about 6 inches shorter. Forage researchers say it should yield well when used to reseed cool-season pastures and rangeland in mid- and short-grass regions.

Beefmaker, an intermediate wheatgrass that's high in protein and highly digestible. It's recommended for yearling stockers.

Haymaker, an intermediate wheatgrass that produces high yields in low rainfall areas. It's intended as a cool-season hay crop for maintaining beef herds.

"All three of these varieties survived the drought we've had in the Plains very well," adds Ken Vogel, an ARS researcher who helped develop the varieties.

\section{Better Bromes, Too}

Across Montana and western states, Montana meadow brome (available from Forage Genetics at 800-253-5766 or www.sroseed.com), is gaining popularity among beef producers for use as a mix in alfalfa hay fields, pastures, and for fall and winter grazing. That's according to Dennis Cash, an Extension forage specialist at Montana State University who was involved in the development of the new variety which was released in 2001 .

"Meadow brome is known for its abundant regrowth after being cut. But one of the limitations of the previous variety Regar is that it was a poor seed producer," says Cash.

He reports that the Canadian varieties Fleet and Paddock were developed with improved yield and seed production, and Montana meadow brome was developed predominately from genetics that trace back to the Paddock variety.

The Montana variety was selected for traits of regrowth, overwintering ability, grazing pressure and seed yield, Cash explains, and says, "Montana has similar forage production to Fleet and Paddock, but significantly higher seed production than Regar."

Cash says they are currently working on trials to create another new variety of meadow brome that has the improved seed production combined with better yield and quality than previous varieties.

Until then, he says meadow brome is still one of the best forage choices for beef producers in the Intermountain West. (He cautions that no studies have been conducted east of Colorado to determine if meadow brome can survive the humidity and disease challenges of more eastern states.)

Cash says, "In Montana, we've seen several producers establishing stands of an alfalfa-meadow brome grass mix primarily for the dual purpose of haying and then stockpiling forage for fall and win- 
ter grazing." He reports that the combination works well, because the grass helps reduce bloat and crown damage. And, the meadow brome appears to be more productive and winter hardy than orchardgrass.

Meadow brome is also proving itself in a multispecies field trial Montana State has been evaluating for the past two growing seasons. The trial includes 30 of the newest varieties from several different grass species, and all of the meadow brome varieties (Fleet, Paddock, Regar, Montana and MacBeth) are out yielding the other grass speciesincluding smooth brome, Cash reports.

He says one other species that is showing good potential in the trial is Alaska brome. "We have two Alaska brome varieties in the test - Hakari (from Barenbrug USA at 800-547-4101 or www.barusa.com) and Blizzard (from Cebeco International Seeds at $800-445-2251$ or www.intlseed.com)-and they are keeping similar production to the meadow bromes."

These varieties are very winter hardy and tend to have the production of smooth brome, explains Cash. He adds, "It's certainly a forage to watch."

In Utah Kevin Jensen also reports that they've developed Cache meadow brome which was released this spring. "It was developed under intensive rotational grazing, significantly out yields Fleet and Regar and does well under drought conditions," Jensen says.

Looking for a good read? Following are some of the ranch and business industry's best bets for books.

No Risk Ranching by Greg Judy.

Based on his personal experience, Judy, a rancher from Missouri, shows how to make a living from the land without owning it. In this useful guide, shares how he went from the threat of foreclosure on a 250 acre farm in 1996 to a profitable cattle operation that today includes contract grazing for other people on 2,800 acres of leased land. Judy shares how to find idle land to lease; calculate the cost of a lease; write a land lease contract; lower risk through custom grazing; promote wildlife; and keep accurate records.
Man Must Measure - Livestock Production by Jan Bonsma.

Out of print since 1983, this popular book is once again available for purchase. It was written by South African animal science professor and researcher Jan Bonsma, who is famed internationally for his knowledge of the relationship of cattle to their environment and to each other. This book outlines beef animal growth characteristics, environmental impacts and fertility, among other traits. Available for \$20 plus shipping at www.bovineengineering.com

Good to Great: Why Some Companies Make the Leap... and Others Don't by Jim Collins

The Real Estate Game: The Intelligent Guide to Decision-Making and Investment by William Poorvu and Jeffrey Cruikshank

Although these are untraditional ranch reads, they share applicable ideas for the ag industry. The first book poses the question: "Can a good company become a great company and if so, how?" and then profiles dozens of examples from companies who have succeeded. The second book listed is suited to anyone considering buying real estate-including ranch land. It provides an insider's perspective on how to spot real estate risks and develop strategies that provide protection and adequate investment returns.

Resource Roundup is compiled by Kindra Gordon. Contributions welcome at kindras@gordonresources.com or call (605)722-7699. 